\title{
Quality of Life and Gestational Diabetes Mellitus: A Review Study
}

\author{
Samira Mokhlesi ${ }^{\circledR}$, Masoumeh Simbar ${ }^{2^{*}}$, Fahimeh Ramezani Tehrani ${ }^{3}$, Nourossadat Kariman ${ }^{4}$, \\ Hamid Alavi Majd ${ }^{5}$
}

\begin{abstract}
Objectives: High-risk pregnancies can affect the quality of life (QOL) of pregnant women due to their complications. QOL involves different dimensions including physical, psychological, and social health of the individuals. Assessing the QOL, especially in mothers with gestational diabetes is important in planning for maternal and newborn care and understanding the need for care for policymakers and the health care association. Therefore, the present study aimed to review the effects of gestational diabetes on QOL during pregnancy. Materials and Methods: In this study, articles indexed in several databases such as PubMed, Science Direct, Scopus, Google Scholar, SID, and Magiran were obtained among which, those related to the QOL of mothers with gestational diabetes were extracted and evaluated based on the aim of the study.

Results: The series of the reviewed studies included 10 articles on the physical, psychological, and social dimensions of the QOL of mothers with gestational diabetes. Most of the examined articles failed to find any significant change in the physical dimension of QOL of mothers with gestational diabetes. The psychological effects of gestational diabetes were diverse and less understandable, therefore, different studies obtained contradictory results in this regard. Three out of four studies examining the social dimension of QOL of women with gestational diabetes showed that mothers' QOL could be jeopardized by social dimension.

Conclusions: In general, the results revealed that gestational diabetes could affect various physical, psychological, and social dimensions of the QOL of mothers. In addition, adequate education should be provided for mothers with diabetes in order to reduce their fear, anxiety, and depression concerning gestational diabetes.

Keywords: Pregnancy, Gestational diabetes, Quality of life
\end{abstract}

\section{Introduction}

Gestational diabetes mellitus (GDM) is considered as the most common medical condition during pregnancy which begins or is diagnosed with different intensities of carbohydrate intolerance during pregnancy. This definition is used regardless of the use or the lack of insulin use for treatment $(1,2)$. The prevalence of GDM is growing worldwide $(3,4)$ and obesity and the increased age of mothers during pregnancy are among the factors involved in an increase in GDM prevalence (5). In a metaanalysis conducted in Iran, the prevalence of GDM was estimated at around $4.9 \%$ (6).

According to the World Health Organization, the quality of life (QOL) refers to a person's perception of their status in life given the culture and value system in which they live, along with the goals, expectations, criteria, and interests of the person of interest (7). In addition, physical, psychological, social, environmental, and personal beliefs affect QOL (8). Today, QOL investigation and registration have obtained great significance as an integrated concept with different dimensions in medical and nursing interventions $(8,9)$.

Women with high-risk pregnancies face problems in their personal, familial, and social life, which can adversely influence their QOL (10). GDM, as one of such problems, causes detrimental medical consequences for the pregnant mother, as well as the fetus and neonate (11). Further, it adversely affects the psychological health and well-being of pregnant mothers, leading to a reduction in the QOL of a pregnant woman's life (12).

Concerning the high and progressive prevalence of GDM and the importance of enhancing QOL of patients with GDM, the current study sought to investigate the impacts of GDM on the QOL of pregnant women.

\section{Materials and Methods}

As previously mentioned, this study assessed the effect of gestational diabetes on the QOL during pregnancy Following the guideline of PRISMA (Preferred Reporting Items for Systematic Reviews and Meta-Analyses) (13). To fulfill the present study, English electronic sources including Medline (via PubMed), Scopus, Web of Science, 
and Science Direct were systematically searched without any time constraints up to 2018. The keywords used to find the research articles included "gestational diabetes OR gestational hyperglycemia" combined using AND Boolean operator with "quality of life". Furthermore, Persian databases such as SID and Magiran were searched using Persian keywords of gestational diabetes and QOL. Two researchers independently reviewed the titles and abstracts of the articles and then extracted and reviewed the full-text articles if the subject matter seemed to be relevant to the purpose of the present study. Finally, those articles that met the inclusion criteria were selected for investigation.

\section{Inclusion Criteria}

- All papers up to 2018 which were qualitative or quantitative;

- Persian and English papers published in domestic and foreign research-scientific journals;

- Papers that dealt with assessing the QOL of mothers of GDM.

\section{Exclusion Criteria}

The exclusion criteria were repeated papers, non-English or Persian papers, those with no well-specified method and sample size, papers which were only related to the QOL of women with diabetes without reporting any special information regarding the GDM subgroup, and finally, papers that measured the effect of GDM on the QOL in the years after pregnancy. The inclusion and exclusion criteria of the papers were applied based on their title and abstract. Eventually, all the eligible papers were examined after removing the papers not qualifying the inclusion criteria.

\section{Results}

Surfing the search engines using suitable keywords, a total of 502 papers were obtained out of which 10 papers were considered suitable and examined accordingly. Figure 1 represents the extracted results. As the QOL in the mentioned studies are presented with respect to physical, psychological, and social dimensions, the results of studies of the QOL of mothers with GDM are summarized in three parts including the physical dimension of the QOL of mothers with GDM (Table 1), the psychological dimension of the QOL of mothers with GDM (Table 2), and the social dimension of the QOL of mothers with GDM (Table 3).

Kopec et al assessed the physical and psychological health of 205 mothers with GDM during weeks 27 and 36 of their pregnancy using demographic and the 36-item short-form health survey (SF-8) questionnaires. Between these two weeks, the scores related to the physical health of mothers decreased briefly and significantly while those of the psychological health in SF-8 demonstrated no change. In addition, the diabetes impact on daily life (e.g., work, school, family, and social life) questionnaire was completed, along with the SF-8 questionnaire. Based on the results, GDM had no influence on the mothers' work or school. However, the number of individuals who

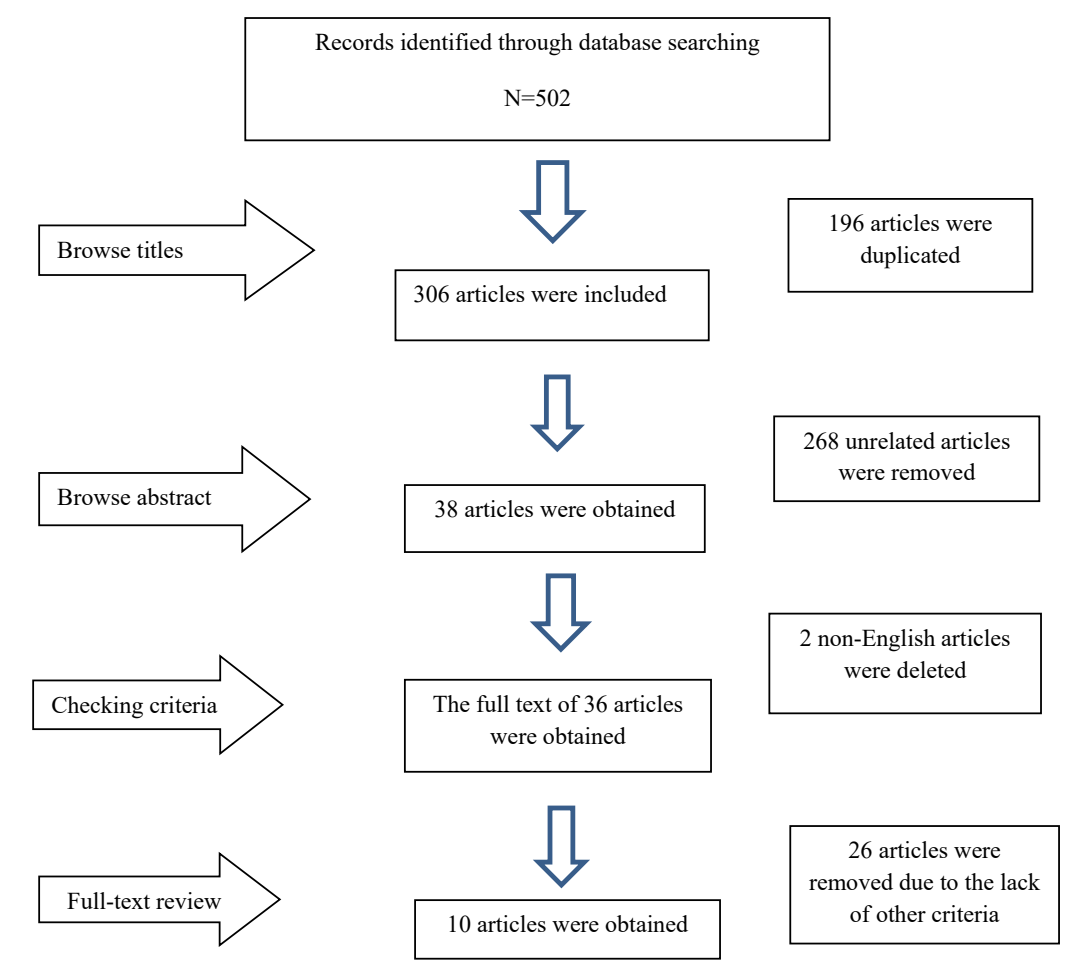

Figure 1. The Flowchart of the Course of Paper Selection. 
Table 1. Characteristics of the Included Studies Respecting Assessing the Impact of GDM on Physical Dimension of the QOL

\begin{tabular}{|c|c|c|c|c|c|}
\hline $\begin{array}{l}\text { Authors/ } \\
\text { Country/Year }\end{array}$ & Study Design & Participants & $\begin{array}{l}\text { Dimension of } \\
\text { QOL }\end{array}$ & $\begin{array}{l}\text { Measure of } \\
\text { QOL }\end{array}$ & Results \\
\hline $\begin{array}{l}\text { Kopec et al, } \\
\text { Poland, } 2015\end{array}$ & Longitudinal study & $\begin{array}{l}205 \text { pregnant women with } \\
\text { GDM }\end{array}$ & Physical & SF-8 & $\begin{array}{l}\text { The physical health of mothers with } \\
\text { GDM did not change in this study }\end{array}$ \\
\hline $\begin{array}{l}\text { Dalfrà et al, Italy, } \\
2012\end{array}$ & $\begin{array}{l}\text { Observational study } \\
\text { with control group }\end{array}$ & $\begin{array}{l}176 \text { pregnant women with } \\
\text { GDM, } 30 \text { pregnant women } \\
\text { with T1DM, } 39 \text { healthy } \\
\text { controls }\end{array}$ & Physical & SF-36 & $\begin{array}{l}\text { Physical health of mothers with GDM } \\
\text { was better compared to healthy } \\
\text { mothers }\end{array}$ \\
\hline $\begin{array}{l}\text { Trutnovsky et al, } \\
\text { Australia, } 2012\end{array}$ & Prospective study & 45 pregnant women with GDM & Physical & WHO-QOL & $\begin{array}{l}\text { A significant decrease was observed } \\
\text { in the mean scores of the physical } \\
\text { dimension from the middle to the end } \\
\text { of pregnancy }\end{array}$ \\
\hline $\begin{array}{l}\text { Halkoaho et al, } \\
\text { Finland, } 2010\end{array}$ & $\begin{array}{l}\text { Observational study } \\
\text { with control group }\end{array}$ & $\begin{array}{l}77 \text { women diagnosed with } \\
\text { GDM, } 54 \text { healthy controls }\end{array}$ & Physical & 15D HRQoL & $\begin{array}{l}\text { The results of the study did not show } \\
\text { a significant difference between the } \\
\text { two groups }\end{array}$ \\
\hline $\begin{array}{l}\text { Mautner et al, } \\
\text { Australia, } 2009\end{array}$ & Longitudinal study & $\begin{array}{l}18 \text { women were affected by } \\
\text { hypertensive disorders, } 11 \\
\text { women were affected by GDM, } \\
32 \text { women were at the risk of } \\
\text { preterm delivery, } 29 \text { healthy } \\
\text { controls }\end{array}$ & Physical & WHO-QOL & $\begin{array}{l}\text { Physical dimension of QOL of women } \\
\text { with gestational diabetes was not } \\
\text { significantly different from that of the } \\
\text { control group }\end{array}$ \\
\hline $\begin{array}{l}\text { Kim et al, } \\
\text { California, } 2005\end{array}$ & Cohort study & $\begin{array}{l}64 \text { women with GDM, } 48 \\
\text { healthy women }\end{array}$ & Physical & SF-36 & $\begin{array}{l}\text { There was no significant difference } \\
\text { between physical activity scores } \\
\text { between the two groups }\end{array}$ \\
\hline $\begin{array}{l}\text { Rumbold \& } \\
\text { Crowther, South } \\
\text { Australia, } 2002\end{array}$ & Prospective study & $\begin{array}{l}21 \text { with positive OGTT (GDM } \\
\text { group), } 124 \text { with negative } \\
\text { OGTT }\end{array}$ & Physical & SF-36 & $\begin{array}{l}\text { The mean score of SF- } 36 \text { was similar } \\
\text { between the two groups regarding the } \\
\text { physical dimension after screening and } \\
\text { in the next stages of pregnancy }\end{array}$ \\
\hline
\end{tabular}

Abbreviations. GDM: Gestational diabetes mellitus; QOL: Quality of life; T1DM: Type 1 diabetes mellitus; OGTT: Oral glucose tolerance test; SF-8: Eight-item short-form health survey; SF-36: Thirty-six-item short-form health survey; WHO-QOL: WHO-QOL-Bref questionnaire; HRQoL: Health-related quality of life.

reported that GDM affects their social life increased from $25 \%$ to $35 \%$ (14). Another study examined the QOL of 245 pregnant mothers (including 30 mothers with Type I diabetes, 176 with GDM, and 39 healthy mothers) in Italy by 36 -Item Short-Form Health Survey questionnaire in the third trimester and post-delivery. Based on the results, the scores of the physical dimension were better in women with Type I diabetes and those with GDM compared to the control group during the third trimester. As regards the standardized psychological dimension scores, no difference was observed between the mothers in GDM and control groups (15). Similarly, Trutnovsky et al studied the QOL of mothers with GDM applying WHO-QOL-Bref questionnaire. The analysis of WHOQOL-Bref indicated a significant reduction in the means of scores related to physical and social dimensions from the middle to the end of pregnancy. In addition to WHOQOL-Bref questionnaire, a semi-structured interview was performed with mothers, the results of which showed a significant decline in the mean scores of psychological dimension from the middle to the end of pregnancy (16). Conversely, in a study in Finland on 100 mothers with GDM and 100 healthy mothers, the QOL was measured by a 15-dimension general QOL questionnaire. However, the results of the study represented no significant differences between the dimensions of QOL including physical activity, discomfort, depression, and distress between the two groups (17). Further, a study conducted in Germany investigated the effect of adverse consequences of pregnancy including GDM on the QOL of 90 mothers (including 29 mothers in the control group) during and after pregnancy. All participants completed the WHOQOL-Bref questionnaire which evaluated physical, psychological, social, environmental, and general health aspects 3 times (i.e., at the first visit, during pregnancy, and post-delivery). The results suggested that the physical dimension during 24-37 weeks diminished significantly compared to 3-4 months post-delivery for all mothers. However, no significant difference was observed between mothers with GDM and healthy mothers. Furthermore, the results demonstrated no significant difference between the healthy and GDM mothers regarding the scores of social dimension (18). Likewise, another study assessed the health conditions (e.g., physical performance, vitality, energy, and self-report health) of 64 women with GDM during a four-stage period using the SF-36 questionnaire and then their results were compared with those of 1233 healthy mothers. The results revealed that although the women with GDM were at a higher risk of self-report health reduction before pregnancy up to the 
Table 2. Characteristics of the Included Studies Regarding Assessing the Impact of GDM on Psychological Dimension of the QOL

\begin{tabular}{|c|c|c|c|c|c|}
\hline $\begin{array}{l}\text { Authors/ Country/ } \\
\text { Year }\end{array}$ & Study Design & Participants & $\begin{array}{l}\text { Dimension of } \\
\text { QOL }\end{array}$ & $\begin{array}{l}\text { Measure of } \\
\text { QOL }\end{array}$ & Results \\
\hline $\begin{array}{l}\text { Bien et al, Poland, } \\
2016\end{array}$ & $\begin{array}{l}\text { Observational study } \\
\text { without control } \\
\text { group }\end{array}$ & $\begin{array}{l}114 \text { pregnant women with } \\
\text { GDM }\end{array}$ & Psychological & WHO-QOL & $\begin{array}{l}\text { The average of psychological scores } \\
\text { was worse than that of physical, social, } \\
\text { and environmental dimensions }\end{array}$ \\
\hline $\begin{array}{l}\text { Kopec et al, Poland, } \\
2015\end{array}$ & Longitudinal study & $\begin{array}{l}205 \text { pregnant women with } \\
\text { GDM }\end{array}$ & Psychological & SF-8 & $\begin{array}{l}\text { The mental health of mothers with } \\
\text { gestational diabetes demonstrated no } \\
\text { change }\end{array}$ \\
\hline $\begin{array}{l}\text { Kutowska et al, } \\
\text { poland, } 2012\end{array}$ & $\begin{array}{l}\text { Observational study } \\
\text { without control } \\
\text { group }\end{array}$ & $\begin{array}{l}100 \text { pregnant women with } \\
\text { GDM }\end{array}$ & Psychological & & $\begin{array}{l}\text { Half of the mothers had a worse mental } \\
\text { state during the treatment compared } \\
\text { to before the diagnosis of diabetes }\end{array}$ \\
\hline $\begin{array}{l}\text { Dalfrà et al, Italy, } \\
2012\end{array}$ & $\begin{array}{l}\text { Observational study } \\
\text { with control group }\end{array}$ & $\begin{array}{l}176 \text { pregnant women with } \\
\text { GDM, } 30 \text { pregnant women } \\
\text { with T1DM, } 39 \text { healthy } \\
\text { controls }\end{array}$ & Psychological & SF-36 & $\begin{array}{l}\text { In the psychological dimension, the } \\
\text { QOL of the participants was not } \\
\text { different }\end{array}$ \\
\hline $\begin{array}{l}\text { Lapolla et al, Italy, } \\
2012\end{array}$ & $\begin{array}{l}\text { Observational study } \\
\text { without control } \\
\text { group }\end{array}$ & $\begin{array}{l}198 \text { pregnant women with } \\
\text { GDM }\end{array}$ & Psychological & $\begin{array}{l}\text { Researcher's } \\
\text { Inventory }\end{array}$ & $\begin{array}{l}\text { Diagnosis of diabetes led to anxiety in } \\
\text { Italian and immigrant women }\end{array}$ \\
\hline $\begin{array}{l}\text { Trutnovsky et al, } \\
\text { Australia, } 2012\end{array}$ & Prospective study & $\begin{array}{l}45 \text { pregnant women with } \\
\text { GDM }\end{array}$ & Psychological & WHO-QOL & $\begin{array}{l}\text { A significant decrease was observed in } \\
\text { the mean of psychological dimension } \\
\text { scores from the middle to the end of } \\
\text { pregnancy }\end{array}$ \\
\hline $\begin{array}{l}\text { Halkoaho et al, } \\
\text { Finland, } 2010\end{array}$ & $\begin{array}{l}\text { Observational study } \\
\text { with control group }\end{array}$ & $\begin{array}{l}77 \text { women diagnosed with } \\
\text { GDM, } 54 \text { healthy controls }\end{array}$ & Psychological & 15D HRQoL & $\begin{array}{l}\text { The results of the study showed no } \\
\text { significant difference between the two } \\
\text { groups in the psychological dimension } \\
\text { of QOL }\end{array}$ \\
\hline $\begin{array}{l}\text { Mautner et al, } \\
\text { Australia, } 2009\end{array}$ & Longitudinal study & $\begin{array}{l}18 \text { women were affected } \\
\text { by hypertensive disorders, } \\
11 \text { women were affected by } \\
\text { GDM, } 32 \text { women were at } \\
\text { the risk of preterm delivery, } \\
29 \text { healthy controls }\end{array}$ & Psychological & WHO-QOL & $\begin{array}{l}\text { The psychological dimension of the } \\
\text { QOL of women with GDM was not } \\
\text { significantly different from that of the } \\
\text { control group }\end{array}$ \\
\hline $\begin{array}{l}\text { Rumbold \& Crowther, } \\
\text { South Australia, } 2002\end{array}$ & Prospective study & $\begin{array}{l}21 \text { with positive OGTT } \\
\text { (GDM group), } 124 \text { with } \\
\text { negative OGTT }\end{array}$ & Psychological & SF-36 & $\begin{array}{l}\text { The mean of SF- } 36 \text { was similar } \\
\text { between the two groups regarding } \\
\text { the psychological dimension after } \\
\text { screening and in the next stages of } \\
\text { pregnancy }\end{array}$ \\
\hline
\end{tabular}

Abbreviation. GDM: Gestational diabetes mellitus; QOL: Quality of life; T1DM: Type 1 diabetes mellitus; OGTT: Oral glucose tolerance test; SF-8: Eight-item short-form health survey; SF-36: Thirty-six-item short-form health survey; WHO-QOL: WHO-QOL-Bref questionnaire; HRQoL: Health-related quality of life.

third trimester, they showed a similar reduction in all measurements of health conditions before pregnancy up to post-delivery compared to healthy individuals. Moreover, there was no significant difference between the physical performance scores between the 2 groups (19). Rumbold et al evaluated the QOL of pregnant women with positive GDM screening by SF-36 questionnaire which was designed for different stages of pregnancy (i.e., before screening the GDM, after the screening test, getting informed about the test results, and in the late third trimester). The mean SF-36 was similar in both groups after screening and during the subsequent stages of screening respecting physical and psychological areas. Based on the findings, women with positive screening and negative GDM diagnostic test had a poorer social performance compared to those with negative screening due to emotional and physical problems (20). Additionally, Bien, using demographic and WHO-QOL questionnaires, studied 114 pregnant mothers with GDM hospitalized in the high-risk pregnancy ward and reported that the mean scores of the psychological dimension of mothers with GDM were lower compared to other dimensions (21). Similarly, Kutowska et al investigated the QOL of 100 women with GDM and the factors affecting their QOL. In most pregnancy mothers, the QOL score decreased by 2.5 scores on average after diagnosing and treating diabetes. In addition, women expressed their dominant psychological status and the sense of security, which worsened during the treatment as compared to the prediagnosis of GDM (22). Further, Lapolla et al studied the QOL of women with GDM and found that GDM diagnosis caused anxiety in Italian and immigrant women 
Table 3. Characteristics of the Included Studies Regarding Assessing the Impact of GDM on Social Dimension of the QOL

\begin{tabular}{|c|c|c|c|c|c|}
\hline $\begin{array}{l}\text { Authors/ } \\
\text { Country/ Year }\end{array}$ & Study Design & Participants & $\begin{array}{l}\text { Dimension od } \\
\text { QOL }\end{array}$ & $\begin{array}{l}\text { Measure of } \\
\text { QOL }\end{array}$ & Results \\
\hline $\begin{array}{l}\text { Kopec et al, } \\
\text { Poland, } 2015\end{array}$ & $\begin{array}{l}\text { Longitudinal } \\
\text { study }\end{array}$ & 205 pregnant women with GDM & Social & SF-8 & $\begin{array}{l}\text { The number of people who reported } \\
\text { that pregnancy-induced diabetes affects } \\
\text { their social lives after the diagnosis of } \\
\text { gestational diabetes increased from } 25 \% \\
\text { to } 35 \%\end{array}$ \\
\hline $\begin{array}{l}\text { Trutnovsky et al, } \\
\text { Australia, } 2012\end{array}$ & $\begin{array}{l}\text { Prospective } \\
\text { study }\end{array}$ & 45 pregnant women with GDM & Social & WHO-QOL & $\begin{array}{l}\text { A significant decrease was observed in the } \\
\text { mean social scores from the middle to the } \\
\text { end of pregnancy }\end{array}$ \\
\hline $\begin{array}{l}\text { Mautner et al, } \\
\text { Australia, } 2009\end{array}$ & $\begin{array}{l}\text { Longitudinal } \\
\text { study }\end{array}$ & $\begin{array}{l}18 \text { women were affected by } \\
\text { hypertensive disorders, } 11 \\
\text { women were affected by GDM, } \\
32 \text { women were at the risk of } \\
\text { preterm delivery, } 29 \text { healthy } \\
\text { controls }\end{array}$ & Social & WHO-QOL & $\begin{array}{l}\text { The social dimension of the QOL of women } \\
\text { with GDM showed no significant difference } \\
\text { as compared to the control group }\end{array}$ \\
\hline $\begin{array}{l}\text { Rumbold \& } \\
\text { Crowther, South } \\
\text { Australia, } 2002\end{array}$ & $\begin{array}{l}\text { Prospective } \\
\text { study }\end{array}$ & $\begin{array}{l}21 \text { with positive OGTT (GDM } \\
\text { group), } 124 \text { with negative OGTT }\end{array}$ & Social & SF-36 & $\begin{array}{l}\text { Women with positive screening and } \\
\text { negative diagnostic tests showed poorer } \\
\text { social performance scores compared to } \\
\text { women with negative screening }\end{array}$ \\
\hline
\end{tabular}

Abbreviations. GDM: Gestational diabetes mellitus; QOL: Quality of life; T1DM: Type 1 diabetes mellitus; OGTT: Oral glucose tolerance test; SF-8: Eight-item short-form health survey; SF-36: Thirty-six-item short-form health survey; WHO-QOL: WHO-QOL-Bref questionnaire; HRQoL: Health-related quality of life.

afflicted with this disease. The major feeling among these women was the fear of adverse consequences of the child (66\%), followed by the concern over abnormalities in the neonate $(29 \%)$. Furthermore, $52 \%$ of the Italian women were almost more optimistic, among whom the concern over neonatal consequences reduced as compared with the worries of immigrant women (23).

\section{Discussion}

In the current review study, the QOL of mothers with GDM was first examined concerning the physical, psychological, and social dimensions. The QOL is regarded as an objective and subjective concept based on personal perception and is affected by physical health, psychological status, and social relations (24). Moreover, it is a clinical concept which determines the individuals' assessment about their health conditions. This subjective assessment, as a psychological factor, can affect the medical consequences of GDM. Additionally, QOL encompasses various physical, psychological, and social health dimensions which can be measured during pregnancy. It is noteworthy that measuring the QOL, especially in mothers with GDM is crucial in planning for mother and neonatal care, as well as understanding the necessity of the existence of such care for policy-makers and healthcare associations (25).

Based on the findings of five out of seven papers, dealt with the physical dimension of QOL of women with GDM, no significant changes were found in the physical dimension of QOL of these mothers. Contrarily, in some studies, mothers with GDM had less physical activity (1, $3,16)$. In the study by Tratnuski et al, the physical activity of the affected mothers decreased during pregnancy (16). However, the above-mentioned study contained no control group and changes during pregnancy and the incidence of discomforts and problems of this period (e.g., nausea, vomiting, fatigue, pain, leg cramps, and the like) could have a considerable effect on the physical activities of pregnant women (25). Therefore, the decreased mean value of the physical dimension of the questionnaire may not be attributed only to GDM. In the study by Macvandi, investigating the QOL of pregnant mothers, the minimum acquired scores were observed in vitality and physical performance dimensions. In addition, the age of pregnancy was introduced as an influential factor in QOL such that an increase in the age of pregnancy led to a decrease in the score of physical dimension (26). However, the results of one study regarding the physical dimension of QOL of mothers with GDM represented the elevated scores of physical dimension as compared to healthy mothers (15) which may be due to the fact that mothers with GDM possibly care more about their health conditions compare to healthy mothers and strive harder to remain in good physical conditions for coping with GDM-associated problems. In the study by Morrison on the experience of Australian mothers with GDM, some participants viewed GDM as an opportunity for changing lifestyle (27). Further, in another study, gaining knowledge about GDM resulted in enhanced motivation and selfefficacy for changing lifestyle (e.g., physical activity and exercise) and the affected mothers modified their lifestyle in order to prevent diabetes in the future (28). On the other hand, the investigated studies may not be quite enough for discovering the difference between women 
with or without GDM. For example, over 100000 women are required to identify a significant difference respecting the changes in physical performance among women with or without GDM (19).

The majority of the examined papers of the present review study failed to find a significant change in the psychological dimension of QOL of mothers with GDM while only Trutnovsky et al (16), Bien (21), and Kutowska et al (22) reported a negative effect of GDM on the psychological dimension of mothers. Indeed, pregnancy is a stressful period for mothers, and high-risk pregnancy can intensify this stress (2). Furthermore, depression, worry, and anxiety are among the important psychological reactions of an individual who is diagnosed with new conditions including GDM (16). The fear and anxiety were among the themes which were extracted from the qualitative study by Morrison about the experience of women with GDM (27). Concern over their own and neonatal health was reported among the worries of mothers with GDM (29).

The psychological effects of GDM are diverse and less understandable, therefore, the results of studies in this regard are contradictory (16). This might be related to the fact that emotional effects during pregnancy are strongly associated with socio-demographic variables such as age, attitude toward pregnancy, and social support (30). Carolan indicated support by family, spouse, and acquaintances as the main factor for adapting to GDM and its self-management (31).

Moreover, the level of awareness and information about GDM and its consequences is considered as another effective factor on depression and anxiety levels of mothers with GDM. In studies in which GDM individuals were under care, those who received adequate information about GDM during pregnancy had less worry and anxiety, and the prevalence of depression was lower among these mothers. Even in mothers receiving insulin, the psychological results were similar to those with mothers who were controlled with diet when they found that better glucose control obtained by insulin can yield better pregnancy consequences (15). Mirfeizi et al, evaluating the effect of education on the QOL of pregnant women with GDM, found that the QOL enhanced in mothers who received an education (32). Additionally, effective and satisfactory communication between pregnant women with GDM and healthcare providers is regarded as another influential factor in the psychological health of GDM mothers (12). For instance, in the study by Lapolla et al, immigrant women with GDM probably failed to establish good communication with healthcare providers due to linguistic barriers, as well as cultural and religious differences, and therefore, experienced more worries during pregnancy (23). Thus, proposing a suitable treatment plan, establishing effective communication, and educating mothers with GDM can motivate and help them feel the sense of security and improve their QOL.

Three out of four studies which focused on the social dimension of the QOL of women with GDM showed that their QOL can be jeopardized in the social dimension and women with high-risk pregnancy face various risks in their personal, family, and social life (33). Mothers with GDM feel that they are socially isolated and a very few numbers of people know about GDM, and this disease is unknown. Further, GDM is a stigma for some women and thus they are ashamed of expressing it $(12,20)$. In a study, only $29 \%$ of women with GDM felt that their husband and other family members (e.g., sister, mother, and spouse family) helped them to cope with pregnancy problems and GDM (23). According to the report by Kopec et al, the level of support for mothers with GDM by friends decreased during pregnancy (14). Similarly, Pearson et al found that women believed that GDM resulted in damaged social relations, and the type of food and the time of its serving were not suitable for many of these individuals in social events. In these cases, some women concealed their disease and ate different types of food while some others unveiled their disease in order not to jeopardize themselves (34).

One of the reasons for the discrepancy in the results of the reviewed studies can be the fact that the QOL of women with GDM was measured by general questionnaires in these studies. Although these types of questionnaires can be valid and reliable, they may overlook important areas related to the unique experience of pregnancy or pregnancy-related conditions. In addition, these questionnaires may not be sensitive enough to measure the QOL of women with GDM. Their use may lead to distorted information possibly because they may neglect the unique views of pregnant women with or without complications (35). Thus, future studies are suggested to evaluate the QOL of mothers with GDM by using a specific QOL questionnaire allocated to these women.

Marchetti et al studied the QOL of mothers with GDM, while not examining the QOL dimensions in particular, and concluded that GDM worsened their QOL in general. The difference between the present study and that of Marchetti et al is that the present study searched different English and Persian databases. Considering the multidimensional nature of QOL and the effect of GDM on each of the dimensions of QOL, suitable interventions and measures can be implemented in order to enhance the QOL of the affected mothers. In the present study, the findings were expressed differently with a focus on the effect of GDM on various physical, psychological, and social dimensions of the QOL.

Healthcare providers and managers at different levels of healthcare organizations can benefit from the results of this study to enhance the QOL of mothers with GDM. These findings can be used in macro research and planning as well. 


\section{Conclusions}

Overall, the results of the studies were contradictory regarding the physical, psychological, and social dimensions of the QOL of mothers with GDM. Generally, sparse studies addressed the QOL of mothers with GDM. Thus, further studies should be conducted in this regard. Further, specialized instruments should be used to assess the QOL of this group of mothers since understanding and evaluating different dimensions of the QOL of these mothers help healthcare providers to organize their activities aiming at enhancing and improving the health and QOL of GDM pregnant mother.

\section{Conflict of Interests}

There is no conflict of interest between authors and financial resources.

\section{Ethical Issues}

Not applicable.

\section{Financial Support}

This study is the result of a Phd thesis and was supported by Shahid Beheshti University, Tehran, Iran.

\section{References}

1. Momeni Javid F, Simbar M, Dolatian M, Alavi Majd $\mathrm{H}$. Comparison of lifestyles of women with gestational diabetes and healthy pregnant women. Glob J Health Sci. 2014;7(2):162-169. doi:10.5539/gjhs.v7n2p162

2. Cunningham F, Leveno K, Hauth J, Rouse D. Williams Obstetrics. McGraw-Hill Professional; 2010.

3. Momeni Javid F, Simbar M, Dolatian M, Alavi Majd H, Mahmoodi Z. A comparative study on dietary style and physical activity of women with and without gestational diabetes. Acta Med Iran. 2016;54(10):651-656.

4. Bener A, Saleh NM, Al-Hamaq A. Prevalence of gestational diabetes and associated maternal and neonatal complications in a fast-developing community: global comparisons. Int J Womens Health. 2011;3:367-373. doi:10.2147/ijwh.s26094

5. Latif L, Hyer S, Shehata H. Metformin effects on treatment satisfaction and quality of life in gestational diabetes. Br J Diabetes Vasc Dis. 2013;13(4):178-182. doi:10.1177/1474651413493933

6. Sayehmiri F, Bakhtiary S, Darvishi P, Sayehmiri K. Prevalence of gestational diabetes mellitus in Iran: a systematic review and meta-analysis study. The Iranian Journal of Obstetrics, Gynecology and Infertility. 2013;15(40):16-23.

7. Bonomi AE, Patrick DL, Bushnell DM, Martin M. Validation of the United States' version of the World Health Organization Quality of Life (WHOQOL) instrument. J Clin Epidemiol. 2000;53(1):1-12. doi:10.1016/S08954356(99)00123-7

8. de Wit M, Delemarre-van de Waal HA, Pouwer F, Gemke RJ, Snoek FJ. Monitoring health related quality of life in adolescents with diabetes: a review of measures. Arch Dis Child. 2007;92(5):434-439. doi:10.1136/adc.2006.102236

9. Bahrami N, Simbar M, Bahrami S. The effect of prenatal education on mother's quality of life during first year postpartum among iranian women: a randomized controlled trial. Int J Fertil Steril. 2013;7(3):169-174.

10. Saadati F, Sehhatiei Shafaei F, Mirghafourvand M. Sleep quality and its relationship with quality of life among high-risk pregnant women (gestational diabetes and hypertension). J Matern Fetal Neonatal Med. 2018;31(2):150-157. doi:10.1080/14767058.2016.1277704

11. Minooee S, Ramezani Tehrani F, Rahmati M, Mansournia MA, Azizi F. Diabetes incidence and influencing factors in women with and without gestational diabetes mellitus: A 15year population-based follow-up cohort study. Diabetes Res Clin Pract. 2017;128:24-31. doi:10.1016/j. diabres.2017.04.003

12. Daniells S, Grenyer BF, Davis WS, Coleman KJ, Burgess JA, Moses RG. Gestational diabetes mellitus: is a diagnosis associated with an increase in maternal anxiety and stress in the short and intermediate term? Diabetes Care. 2003;26(2):385-389. doi:10.2337/diacare.26.2.385

13. Moher D, Liberati A, Tetzlaff J, Altman DG. Preferred reporting items for systematic reviews and meta-analyses: the PRISMA statement. PLoS Med. 2009;6(7):e1000097. doi:10.1371/journal.pmed.1000097

14. Kopec JA, Ogonowski J, Rahman MM, Miazgowski T. Patient-reported outcomes in women with gestational diabetes: a longitudinal study. Int J Behav Med. 2015;22(2):206-213. doi:10.1007/s12529-014-9428-0

15. Dalfra MG, Nicolucci A, Bisson T, Bonsembiante B, Lapolla A. Quality of life in pregnancy and post-partum: a study in diabetic patients. Qual Life Res. 2012;21(2):291-298. doi:10.1007/s11136-011-9940-5

16. Trutnovsky G, Panzitt T, Magnet E, Stern C, Lang U, Dorfer M. Gestational diabetes: women's concerns, mood state, quality of life and treatment satisfaction. J Matern Fetal Neonatal Med. 2012;25(11):2464-2466. doi:10.3109/14767 058.2012.683900

17. Halkoaho A, Kavilo M, Pietila AM, Huopio H, Sintonen H, Heinonen S. Does gestational diabetes affect women's health-related quality of life after delivery? Eur J Obstet Gynecol Reprod Biol. 2010;148(1):40-43. doi:10.1016/j. ejogrb.2009.09.025

18. Mautner E, Greimel E, Trutnovsky G, Daghofer F, Egger JW, Lang U. Quality of life outcomes in pregnancy and postpartum complicated by hypertensive disorders, gestational diabetes, and preterm birth. J Psychosom Obstet Gynaecol. 2009;30(4):231-237. doi:10.3109/01674820903254757

19. Kim C, Brawarsky P, Jackson RA, Fuentes-Afflick E, Haas JS. Changes in health status experienced by women with gestational diabetes and pregnancy-induced hypertensive disorders. J Womens Health (Larchmt). 2005;14(8):729736. doi:10.1089/jwh.2005.14.729

20. Rumbold AR, Crowther CA. Women's experiences of being screened for gestational diabetes mellitus. Aust N Z J Obstet Gynaecol. 2002;42(2):131-137. doi:10.1111/j.00048666.2002.00131.x

21. Bien A, Rzonca E, Kanczugowska A, Iwanowicz-Palus G. Factors affecting the quality of life and the illness acceptance of pregnant women with diabetes. Int J Environ Res Public Health. 2015;13(1):ijerph13010068. doi:10.3390/ 
ijerph13010068

22. Kutowska U, Gierszewska M, Mieczkowska E, Gebuza G, Kazmierczak M. Quality of life among women with gestational diabetes mellitus. Med Biol Sci. 2012;26(1):133138. doi:10.12775/4103

23. Lapolla A, Di Cianni G, Di Benedetto A, et al. Quality of life, wishes, and needs in women with gestational diabetes: Italian DAWN pregnancy study. Int J Endocrinol. 2012;2012:784726. doi:10.1155/2012/784726

24. Cepeda-Valery B, Cheong AP, Lee A, Yan BP. Measuring health related quality of life in coronary heart disease: the importance of feeling well. Int J Cardiol. 2011;149(1):4-9. doi:10.1016/j.ijcard.2010.09.048

25. Bagheri A, Abbaszadeh F, Mehran N. Quality of life in pregnant women. Payesh. 2010;9(1):69-75. [Persian].

26. Macvandi S. Quality of life in pregnant women. Journal of Kermanshah University of Medical Sciences. 2012;16:3742. [Persian].

27. Morrison MK, Lowe JM, Collins CE. Australian women's experiences of living with gestational diabetes. Women Birth. 2014;27(1):52-57. doi:10.1016/j.wombi.2013.10.001

28. Evans MK, O'Brien B. Gestational diabetes: the meaning of an at-risk pregnancy. Qual Health Res. 2005;15(1):66-81. doi:10.1177/1049732304270825

29. Nolan JA, McCrone S, Chertok IR. The maternal experience of having diabetes in pregnancy. J Am Acad Nurse Pract. 2011;23(11):611-618. doi:10.1111/j.17457599.2011.00646.x
30. Kerbel D, Glazier R, Holzapfel S, Yeung M, Lofsky S. Adverse effects of screening for gestational diabetes: a prospective cohort study in Toronto, Canada. J Med Screen. 1997;4(3):128-132. doi:10.1177/096914139700400303

31. Carolan M. Women's experiences of gestational diabetes self-management: a qualitative study. Midwifery. 2013;29(6):637-645. doi:10.1016/j.midw.2012.05.013

32. Mirfeizi M, Mehdizadeh Tourzani Z, Asghari Jafarabadi M, Moghimi Hanjani S, Hasanzad M. Health Education in Gestational Diabetes Mellitus and Quality of Life. J Midwifery Reproductive Health. 2017;5(4):1066-1074. doi:10.22038/jmrh.2017.9256

33. Sittner BJ, DeFrain J, Hudson DB. Effects of high-risk pregnancies on families. MCN Am J Matern Child Nurs. 2005;30(2):121-126.

34. Persson M, Winkvist A, Mogren I. 'From stun to gradual balance'--women's experiences of living with gestational diabetes mellitus. Scand J Caring Sci. 2010;24(3):454-462. doi:10.1111/j.1471-6712.2009.00735.x

35. Mogos MF, August EM, Salinas-Miranda AA, Sultan DH, Salihu HM. A systematic review of quality of life measures in pregnant and postpartum mothers. Appl Res Qual Life. 2013;8(2):219-250.

36. Marchetti D, Carrozzino D, Fraticelli F, Fulcheri M, Vitacolonna E. Quality of life in women with gestational diabetes mellitus: a systematic review. J Diabetes Res. 2017;2017:7058082. doi:10.1155/2017/7058082

(C) 2019 The Author (s); This is an open-access article distributed under the terms of the Creative Commons Attribution License (http://creativecommons.org/licenses/by/4.0), which permits unrestricted use, distribution, and reproduction in any medium, provided the original work is properly cited. 